\title{
Front Matter: Volume 10093
}

, "Front Matter: Volume 10093," Proc. SPIE 10093, Synthesis and Photonics of Nanoscale Materials XIV, 1009301 (9 May 2017); doi: 10.1117/12.2276122

SPIE. Event: SPIE LASE, 2017, San Francisco, California, United States 


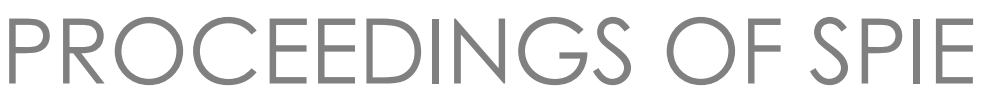

\title{
Synthesis and Photonics of Nanoscale Materials XIV
}

\author{
David B. Geohegan \\ Jan J. Dubowski \\ Andrei V. Kabashin \\ Editors
}

30 January - 1 February 2017

San Francisco, California, United States

Sponsored and Published by

SPIE 
The papers in this volume were part of the technical conference cited on the cover and title page. Papers were selected and subject to review by the editors and conference program committee. Some conference presentations may not be available for publication. Additional papers and presentation recordings may be available online in the SPIE Digital Library at SPIEDigitallibrary.org.

The papers reflect the work and thoughts of the authors and are published herein as submitted. The publisher is not responsible for the validity of the information or for any outcomes resulting from reliance thereon.

Please use the following format to cite material from these proceedings:

Author(s), "Title of Paper," in Synthesis and Photonics of Nanoscale Materials XIV, edited by David B. Geohegan, Jan J. Dubowski, Andrei V. Kabashin, Proceedings of SPIE Vol. 10093 (SPIE, Bellingham, WA, 2017) Seven-digit Article CID Number.

ISSN: 0277-786X

ISSN: 1996-756X (electronic)

ISBN: 9781510606272

ISBN: 9781510606289 (electronic)

Published by

SPIE

P.O. Box 10, Bellingham, Washington 98227-0010 USA

Telephone +1 3606763290 (Pacific Time) · Fax +1 3606471445

SPIE.org

Copyright (c) 2017, Society of Photo-Optical Instrumentation Engineers.

Copying of material in this book for internal or personal use, or for the internal or personal use of specific clients, beyond the fair use provisions granted by the U.S. Copyright Law is authorized by SPIE subject to payment of copying fees. The Transactional Reporting Service base fee for this volume is $\$ 18.00$ per article (or portion thereof), which should be paid directly to the Copyright Clearance Center (CCC), 222 Rosewood Drive, Danvers, MA 01923. Payment may also be made electronically through CCC Online at copyright.com. Other copying for republication, resale, advertising or promotion, or any form of systematic or multiple reproduction of any material in this book is prohibited except with permission in writing from the publisher. The CCC fee code is 0277-786X/17/\$18.00.

Printed in the United States of America.

Publication of record for individual papers is online in the SPIE Digital Library.

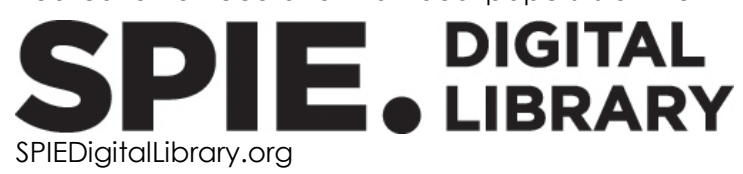

Paper Numbering: Proceedings of SPIE follow an e-First publication model. A unique citation identifier (CID) number is assigned to each article at the time of publication. Utilization of CIDs allows articles to be fully citable as soon as they are published online, and connects the same identifier to all online and print versions of the publication. SPIE uses a seven-digit CID article numbering system structured as follows:

- The first five digits correspond to the SPIE volume number.

- The last two digits indicate publication order within the volume using a Base 36 numbering system employing both numerals and letters. These two-number sets start with 00, 01, 02, 03, 04, 05, 06, 07, 08, 09, OA, OB ... OZ, followed by 10-1Z, 20-2Z, etc. The CID Number appears on each page of the manuscript. 


\title{
Contents
}

\author{
$\checkmark$ Authors \\ vii Conference Committee
}

NANOPARTICLES: LASER INTERACTIONS AND FUNCTIONAL ARCHITECTURES

10093 OA Ultra-short laser interactions with nanoparticles in different media: from electromagnetic to thermal and electrostatic effects (Invited Paper) [10093-9]

\section{CONTROL OF ENERGY FLOW AT THE NANOSCALE: SYNTHESIS AND APPLICATIONS}

10093 OG Phase singularities in 3D plasmonic crystal metamaterials for ultra-sensitive biosensing [10093-15]

LASER PROCESSING WITH PLASMONICS: JOINT SESSION WITH CONFERENCES 100931 AND 10093

$10093 \mathrm{Ol}$ Investigation of gold and bimetallic gold/silver nanoparticles in soda-lime-silicate glasses formed by means of excimer laser irradiation [10093-17]

LASER GENERATED NANOSTRUCTURES: JOINT SESSION WITH CONFERENCES 100931 AND 10093

10093 OK Ultrafast laser patterning and defect generation in titania nanotubes for the enhancement of optical and photocatalytic properties [10093-19]

POSTER SESSION

10093 ON Effect of permittivity on periodic nanostructures by femtosecond laser irradiation on Ti plate [10093-22]

1009300 An all-optical, in situ diagnostic for large molecule and nanoparticle detection [10093-24] 
Proc. of SPIE Vol. $100931009301-4$

Downloaded From: https://www.spiedigitallibrary.org/conference-proceedings-of-spie on 26 Apr 2023 Terms of Use: https://www.spiedigitallibrary.org/terms-of-use 


\title{
Authors
}

Numbers in the index correspond to the last two digits of the seven-digit citation identifier (CID) article numbering system used in Proceedings of SPIE. The first five digits reflect the volume number. Base 36 numbering is employed for the last two digits and indicates the order of articles within the volume. Numbers start with 00, 01, 02, 03, 04, 05, 06, 07, 08, 09, 0A, OB...0Z, followed by 10-1Z, 20-2Z, etc.

\author{
Aristov, Andrey I., OG \\ Arul, Rakesh, OK \\ Danilov, Artem, OG \\ Dong, Junzhe, OK \\ Dubiel, M., 0 l \\ Farsari, Maria, OG \\ Fotakis, Costas, OG \\ Gao, Wei, OK \\ Gerakis, Alexandros, 00 \\ Heinz, M., Ol \\ Hoell, A., 01 \\ Ihlemann, J., Ol \\ Itina, Tatiana E., OA \\ Kabashin, Andrei $\mathrm{V}_{\text {., OG }}$ \\ Manousidaki, Maria, OG \\ Meinertz, J., Ol \\ Miyake, M., ON \\ Ooga, T., ON \\ Oosterbeek, Reece N., OK \\ Raitses, Yevgeny, 00 \\ Sato, Y., ON \\ Shneider, Mikhail N., 00 \\ Simpson, M. Cather, OK \\ Stratton, Brentley C., $0 \mathrm{O}$ \\ Terzaki, Konstantina, OG \\ Tsukamoto, M., ON
}


Proc. of SPIE Vol. 10093 1009301-6

Downloaded From: https://www.spiedigitallibrary.org/conference-proceedings-of-spie on 26 Apr 2023 Terms of Use: https://www.spiedigitallibrary.org/terms-of-use 


\section{Conference Committee}

Symposium Chairs

Reinhart Poprawe, Fraunhofer-Institut für Lasertechnik (Germany)

Koji Sugioka, RIKEN (Japan)

Symposium Co-chairs

Guido Hennig, Daetwyler Graphics AG (Switzerland)

Yongfeng Lu, University of Nebraska-Lincoln (United States)

Program Track Chairs

Beat Neuenschwander, Berner Fachhochschule Technik und

Informatik (Switzerland)

Henry Helvajin, The Aerospace Corporation (United States)

\section{Conference Chairs}

David B. Geohegan, Oak Ridge National Laboratory (United States)

Jan J. Dubowski, University de Sherbrooke (Canada)

Andrei V. Kabashin, Lasers, Plasmas et Procédés Photoniques (France)

\section{Session Chairs}

1 Synthesis and Optoelectronic Properties of 2D Materials and Heterostructures I

David B. Geohegan, Oak Ridge National Laboratory (United States)

2 Synthesis and Optoelectronic Properties of 2D Materials and Heterostructures II

Jan J. Dubowski, University de Sherbrooke (Canada)

3 Nanoparticles: Laser Interactions and Functional Architectures

Andrei V. Kabashin, Lasers, Plasmas et Procédés Photoniques (France)

4 Control of Energy Flow at the Nanoscale: Synthesis and Applications Tatiana E. Itina, Laboratoire Hubert Curien (France) 
5 Laser Processing with Plasmonics: Joint Session with Conferences 10091 and 10093

David B. Geohegan, Oak Ridge National Laboratory (United States)

6 Laser Generated Nanostructures: Joint Session with Conferences 10091 and 10093

Theobald Lohmueller, Ludwig-Maximilians-Universität München (Germany) 